\title{
THE RELATIONSHIP BETWEEN CORPORATE ENTREPRENEURSHIP AND FIRM PERFORMANCE: EVIDENCE FROM MALAYSIAN LARGE COMPANIES
}

\author{
Sylvia Nabila Azwa Ambad* \\ Universiti Teknologi MARA \\ Kalsom Abdul Wahab \\ Universiti Sains Islam Malaysia
}

\begin{abstract}
The present study is focused on the effects of corporate entrepreneurship (CE) on performance of large sized firms in Malaysia. These companies are currently facing more challenging environments compared to past, as their survival rates are declining and suffering from low level of profitability. The paper uses survey method and secondary sources by collecting data from 130 companies listed in the main market of Bursa Malaysia. In order to analyze the survey data, the study uses Partial Least Squares (PLS) approach to Structural Equation Modelling (SEM). This study has concluded that the entrepreneurial orientation (EO) is positively related to firm's profitability but has no relationship with firm's growth whereas corporate venturing (CV) is positively related to firm's growth but has no relationship with firm's profitability. The environmental dynamism moderates these relationships. The paper has significant implications for the top management decision making on the importance of CE on firm growth and profitability. Besides, in developing countries like Malaysia, most of the researches on entrepreneurship are based on small firms or individual entrepreneurships. Thus, it is timely to conduct research on CE among the large sized firms to further expand the literature.
\end{abstract}

Keywords: Corporate Entrepreneurship; Corporate Venturing; Entrepreneurial Orientation; Firm Performance; Large Firm;Partial Least Squares (PLS).

\section{INTRODUCTION}

Studies on strategic management have shown that corporate entrepreneurship (CE) is the main source of superior firm performance (Antoncic \& Hisrich, 2003; Jiang et al., 2014; Reijonen et al., 2015). Although there is no consensus among the researchers on the dimensions of $\mathrm{CE}$, entrepreneurial orientation (EO) and corporate venturing (CV)

\footnotetext{
*Corresponding Author: Faculty of Business Management, Universiti Teknologi MARA Sabah Branch, $88997 \quad K o t a \quad K i n a b a l u, \quad$ Sabah. +60-138812994. E-Mail: nabilazwa@gmail.com, nabila1793@sabah.uitm.edu.my.
} 
are widely used as proxies of CE. Recently EO has been commonly accepted as an instrument for capturing a firm's inclination towards entrepreneurship which has been conceptualized as possessing three main characteristics which are; innovativeness, risktaking, and proactiveness (Covin \& Wales, 2011; Liu \& Lee, 2015). The CV is always associated with CE or labelled as "intrapreneuring" by Gifford Pinchot due to the fact that it is an entrepreneurial effort to create a new business within an existing firm (Dess \& Lumpkin, 2005). The CE is a term used to explain the entrepreneurial efforts of an established and large organisation (Burns, 2005). Various authors have used various terms to describe entrepreneurial behaviour inside existing firms (Sharma \& Chrisman, 1999). Among the terms used to describe entrepreneurial behaviour at the firm level are intrapreneuring (Pinchot, 1985), corporate entrepreneurship (CE) (Burgelman, 1983; Guth \& Ginsberg, 1990; Covin \& Miles, 1999; Morris et al., 2008; Sharma \& Chrisman, 1999), corporate venturing (von Hippel, 1977; MacMillan et al., 1986; Vesper, 1990), innovative (Miller \& Friesen, 1983), firm-level entrepreneurial posture (Covin, 1991; Covin \& Slevin, 1986), firm’s EO (Knight, 1997; Lumpkin \& Dess, 1996), and organisational entrepreneurship (Handfield et al., 2009; Stevenson et al., 1985). However, CE is the term that is often used to describe entrepreneurial behaviour of large firms.

Despite a large body of literature that has empirically studied the effects of the CE on firm performance, limited empirical research exists on studies about the public-listed companies (PLCs) (Miller \& Miller-Breton, 2011) and large firms. Nowadays, the performance of the PLCs has been a major concern as they are facing more challenging environments as compared to the challenges faced by PLCs in the past. This is proven as the survival rates of the listed firms are found to be declining (Fama \& French, 2004). According to the Deputy Finance Minister of Malaysia Donald Lim Siang Chai in his speech, between $1^{\text {st }}$ January 2003 and $15^{\text {th }}$ July 2010, there were 143 public listed companies that have financial difficulties. From these number, 99 companies were delisted from the official list of Bursa Malaysia. These PLCs were facing financial distress as their loan amount was higher than the value of their assets and were thus, exposed to bankruptcy (The Sun Daily, 2010).

Majority of the researches on entrepreneurship in Malaysia are predominant by the small and medium sized firms. This is due to the fact that, SMEs accounted for 645,136 firms or $97.3 \%$ of the total firm establishment as at year 2010 (Department of Statistics, 2012). Thus, neglecting the importance of entrepreneurial activities among the large firms. Large and small firms face completely different challenges (Beaver, 2003) and thus, both have to adopt different business strategies to achieve high performance (Wagner \& Hansen, 2005). For example, in generating innovation, large and small firms face different managerial and technical issues (Knight, 1989). Studies have found that the manufacturing and innovation strategies employed by the large and small firms also differ (Wagner \& Hansen, 2005; Zahra \& George, 2002). Accordingly, it is important to conduct separate studies on the effects of $\mathrm{CE}$ on firm performance according to the 
firm's size. This is because it is questionable whether the results of studies on small firms can be generalized to larger firms and vice versa, largely due to the fact that all core references with smalls firms as the samples use the perceptual performance data (Andersén, 2010).

The study on the determinant factors of the large firms is essential because the large sized firms in Malaysia are the largest contributor to the Malaysian economic growth. For example, in other developed Asian countries like Japan, Korea, Taiwan and others, their economic growth is significantly generated by SME activities. The percentage of contribution of the SMEs to the Gross Domestic Product (GDP)/total value added represent more than 55\%, ranging from 60\% in China, 57\% in Germany, 55.3\% in Japan and 50\% in Korea (Bank Negara Malaysia, 2005). In contrast, in Malaysia, large firms are the major contributor to the Malaysian GDP. For example, as at 2015, large firms in Malaysia contributed $66.9 \%$ to the GDP. Similarly, the large firms also contributed a substantial amount to the total export. For example in 2014, the contribution of these large firms to the country's total exports was $83 \%$. In other words, the Malaysian large firms contribute a sizable amount of revenue to the Malaysian economy.

In this current study, it is aimed to investigate the effects of the CE dimensions namely the EO and CV on the firm's actual profitability and growth. In addition, the impact of the environmental dynamism has been analyzed as moderating variable between $\mathrm{CE}$ and firm performance. This research study has made important contributions to at least three areas of research. Firstly, usually in developing countries like Malaysia, most of the researches on entrepreneurship were carried out predominantly on small firms or individual entrepreneurships (Miller \& Breton-Miller, 2011) but in reality, large firms face different challenges than the challenges faced by the small firms. This is generally due to the fact that both types of firms have different organisational designs and management styles. Secondly, the current research contributes to the expansion of literature on CE because in Malaysia the research on CE is still infancy. To the best of the author's knowledge, this research is the first study to simultaneously test the EO and $\mathrm{CV}$ on an actual large firm performance by adding the moderating effect of the environmental dynamism. Thirdly, this research study contributes towards the methodology of research, whereas, the previous studies on CE used primary data and combination of firm performance. This study uses objective data and multidimensional construct of firm performance.

This article has been organized as follows: the first section summarizes the most relevant literature upon which the theoretical framework and hypotheses are based. Next, discussion of methodology used in this study. Then, presentation of the results of the empirical analysis. Last but not least, the paper ends with discussion and conclusion part. 


\section{LITERATURE REVIEW}

\subsection{Theoretical Framework}

The theoretical framework (Figure 1) is based on the objective of the study which is to examine the effects of CE dimensions on large firms performance. The hypotheses for this study are also formulated based on the theoretical framework as discussed in the later sections.

Figure 1: Theoretical Framework of the Study

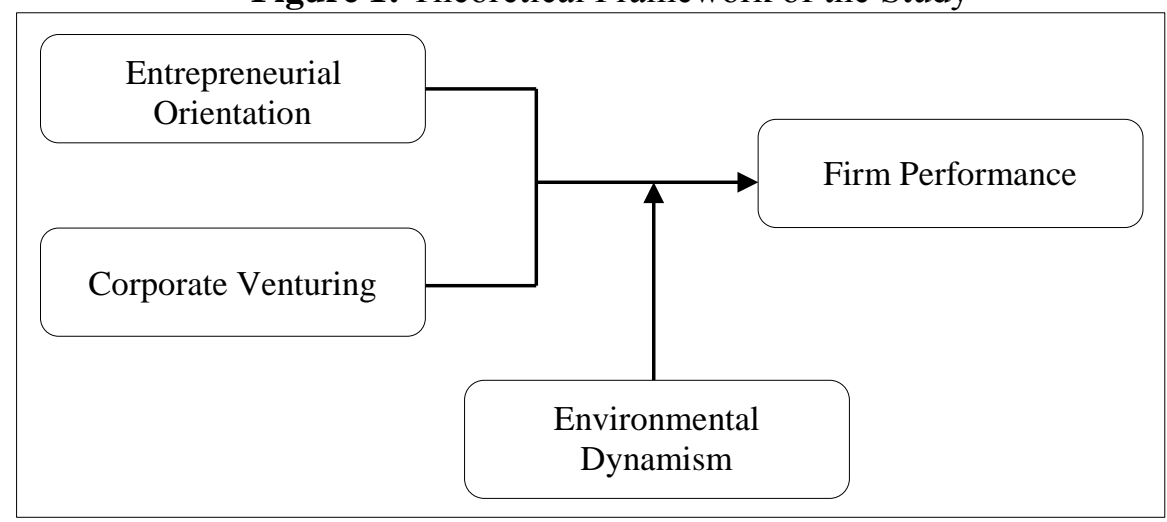

\subsection{Entrepreneurial Orientation (EO) and Firm Performance}

EO refers to the processes, practices and decision-making activities that lead to a new entry as characterized by one or more of the following dimensions: a willingness to innovate, take-risks and proactive relative to market place opportunities (Lumpkin \& Dess, 1996:136-137). These three characteristics namely, the innovativeness, proactiveness and risk taking are the dimensions of EO and the main ingredients for the firms to be entrepreneurial.

The relationship between EO and firm performance has received a huge attention within the literature of various fields due to its importance on the firm's competitiveness and performance. Even though the researchers have agreed EO to be a part of CE, it has attracted more attentions as compared to the CE itself (Covin \& Lumpkin, 2011). There has been a significant increase in articles regarding $\mathrm{EO}$ and firm performance because it is believed that EO is not only essential for a firm's growth (Antoncic \& Scarlat, 2008; Covin et al., 2006; Soininen et al., 2011), but also for profitability (Antoncic, 2007; Lumpkin \& Dess, 2001) , as well as the overall firm's performance (Jantunen et al., 2005; Keh et al, 2007; Tajeddini, 2010). 
This is also being supported by the results of recent meta-analysis suggesting that EO is indeed a significant predictor of firm performance (Rauch et al., 2009). The previous results also showed that studies on EO-firm performance is not only sustainable in a short term but also this relationship has increased over a long term (Wiklund, 1999; Zahra \& Covin, 1995; Zahra, 1991). Hence, the investment in EO may be worthwhile for the firm not only in short term but also in the following years (Wiklund, 1999).

A cross-cultural study found that the EO of the small firms in the US and Netherlands shows positive effect on profitability (Kemelgor, 2002). Another cross-cultural study among 1671 of small and medium sized enterprises also found that all three dimensions of EO are positively related to firm's profitability (Kreiser et al., 2002). The profitability of the Korean micro and small firms are also higher when the firms increased its innovativeness, proactiveness and risk taking (Yoo, 2001). Recent study among the public listed companies in Istanbul, Turkey also found that innovativeness, proactiveness and risk taking are positively related to financial performance (Karacaoglu et al., 2013). Zahra and Garvis (2000) found that the EO of the small and large firms in the US is positively related to the firms' profitability.

The EO also has a positive effect on firm growth. This is found in the previous researches such as the study conducted among the Spanish small firms (Moreno \& Casillas, 2008), SMEs in north-east China (Zhang \& Zhang, 2012), US micro, small and large firms (Covin et al., 2006), Slovenian large manufacturing firms (Antoncic \& Hisrich, 2003) and Finnish small private limited companies (Soininen et al., 2011). Soininen et al. (2011) found that the EO is positively related to firm growth but has no relationship with firm profitability. However there were also studies that found that EO is positively related to both firm growth and profitability such as the studies conducted among the large and small Romanian and Slovenian firms (Antoncic \& Scarlat, 2008), small to large firms in the US (Zahra \& Garvis, 2000) and study among Finnish software companies (Hakala, 2013). Therefore, this study assesses the effects of EO on two dimensions of firm performance (profitability and growth). Thus, two hypotheses were formulated for the direct effect between EO and firm's profitability and growth as follows:

Hypothesis 1a: There is a direct positive relationship between EO and large firms' profitability.

Hypothesis 1b: There is a direct positive relationship between EO and large firms' growth. 


\subsection{Corporate Venturing (CV) and Firm Performance}

$\mathrm{CV}$ is one of the CE components that emphasises on the creation of new business inside or outside the existing organization (Sharma \& Chrisman, 1999). Among CV activities are entering new industries, acquisition, sponsoring new venture activities, and launching new business (Dalziel, 2005; Zahra, 1991). The purpose to launch CV in established firms is varied. Generally, the firms frequently use CV to gain access to ideas, discoveries, technologies, innovations, business practices and to enhance business growth and profitability (Narayanan et al., 2009).

Previous research showed that CV activities generate economic benefits for the parent corporation and improve its financial performance (Antoncic \& Hisrich, 2001). The research by Antoncic and Hisrich (2001) showed a strong relationship between CV and financial performance (return on assets, return on equity, and relative profitability). CV is also often used as a strategy in the declining businesses whereby their corporation is transformed into new core businesses with better opportunities for growth (Donahoe et al., 2001). For this situation, Nokia is the best example as they have successfully transformed their core business; from manufacturing to telecommunications. As proposed by the organizational learning theorists, CV can improve the learning of new skills and competencies, and thus, will facilitate and accelerate the firm's competitiveness and increase its profitability. It is believed that, new and diverse knowledge can be implemented in the business operations and transform the idea into new products or services. Thus, two hypotheses were formulated for the direct effect between $\mathrm{CV}$ and firm's profitability and growth as follows:

Hypothesis 2a: There is a direct positive relationship between CV and large firms' profitability.

Hypothesis 2b: There is a direct positive relationship between CV and large firms' growth.

\subsection{Environmental dynamism as a Moderating Variables}

The importance of dynamic nature of the environment to the relationship between firm's CE and firm performance has repeatedly being confirmed by the scholars (Wiklund \& Shepherd, 2005). The dynamism is often called as uncertainty (Miller \& Friesen, 1983). It is characterized by the rate of change and innovation of the industry and also the unpredictable actions by competitors and customers (Miller \& Friesen, 1983; Lawrence \& Lorsch, 1967; Burns \& Stalker, 1961). The literature suggests that the influence of CE on performance becomes more intense when the firm operates in a dynamic environment (Moreno \& Casillas, 2008). In other words, highly entrepreneurial firm will achieve better performance in a dynamic environment (Lumpkin \& Dess, 2001). 
Previous studies also concluded that the dynamicity of the environment encourages firms to take part in new product innovation activities than those operating in a stable environment (Miller \& Friesen, 1983; Miller, 1988; Zahra, 1993). The firm's failure to respond to dynamic environment will result to loss in market shares and sales, hence will be left out from the competition (Miller, 1988). The persuasion of revolutionary technologies and progressive activities is a great way for setting up a dynamic environment, which is also a plus point for the firm over its competitors (Zahra \& Bogner, 2000; Zahra,1996).

The dynamic environments trigger the effort of the firm to venture into new business as a respond to the challenges and changes in the business environment. In dynamic environment setting, the condition of an industry is unstable and changes continuously. The social, political, technological, and economic changes bring new ideas to the firms to venture into new markets and broadening the firm's niche (Zahra, 1991). The change in the environment creates more opportunities that enables the firm to pursue new innovative ventures in order to benefit from these environment characteristics. Thus, in order to pursue into a venture, the firm will employ newer technologies and innovative marketing practices (Oster, 1990). In addition, the firm will diversify its business to cope with the intensified environment and to avoid failure. Hence, venturing into new business helps the firm to respond to the intense competition and taking the opportunities for growth. Thus, in order to test the interaction effects model, four additional hypotheses were formulated as follows:

Hypothesis 3a: Environmental dynamism moderates the relationship between EO and large firm's profitability. EO is more positively associated with large firm's profitability in dynamic environments.

Hypothesis 3b: Environmental dynamism moderates the relationship between $\mathrm{CV}$ and large firm's profitability. EO is more positively associated with large firm's profitability in dynamic environments.

Hypothesis 4a: Environmental dynamism moderates the relationship between EO and large firm's growth. CV is more positively associated with large firm's growth in dynamic environments.

Hypothesis 4b: Environmental dynamism moderates the relationship between CV and large firm's growth. CV is more positively associated with large firm's growth in dynamic environments. 


\section{METHODOLOGY}

\subsection{Data and Measures}

The primary data for independent and moderating variables have been collected through mail surveys done by a structured questionnaire. The questionnaires were addressed to top management team within a company with designation of senior manager, chief executive officer, vice president, president, or executive director. Out of 660 mailed surveys, only 130 were returned with a usable response, resulting in $19.6 \%$ response rate.

The independent variables instrumentation, which is the EO, was adapted from Lumpkin and Dess (2001) and Lumpkin (1996). For moderating variable, which is the environmental dynamism, was adapted from Miller and Friesen (1982). All responses were measured using seven-point scale items, ranging from " $1=$ strongly disagree" to "7=strongly agree". The actual data for firm performance such as Returned on Assets (ROA) and Return on Sales (ROS) were obtained from the company's annual reports.

To prepare the secondary data for firm performance, the difference between a company's performance score and its industry average was computed, and then divided by the industry's average (for the past three years). The outcome of this process was then multiplied by 100 . The results showed how much better (or worse) a company performs than its average industry competitor (Zahra \& Covin, 1995:53). This step is important because the sample consists of various industries. Thus, it is essential to control the variations in industry performance prior to testing the hypotheses. This was done following the approach suggested by de Vasconcellos e Sa and Hambrick (1989), and Zahra and Covin (1995).

\subsection{Sample Characteristics}

The respondent firms ranged across 14 industrial sectors, where 38 firms (29.2\%) are in the industrial product sector, which is the highest number of firms in a particular sector, followed by consumer product sector with 34 firms (26.2\%). Only 11 firms (8.5\%) have been established in less than 10 years, while the rest have been established within 10 years and above. 113 (86.8\%) firms have been public-listed more than 5 years and only 17 (13.2\%) firms have been established in less than 15 years. Lastly, in terms of number of employees, 99 (76.2\%) firms have more than 300 employees and 31 (23.8\%) have less than 300 employees.

In terms of individual respondent's characteristics, it is revealed that the majority of the respondents are male, 83 (63.8\%) and 47 (36.2\%) are female respondents. Most of the respondents are above 30 years old, 122 (93.9\%) and 62 (47.7\%) are Chinese followed closely by Malay, 56 (43.1\%) respondents. In regards to the respondents' educational 
qualifications, more than half of the respondents have a Bachelor's Degree, 56.9\% (74). With respect to working experience, 81.5\% (106) of the respondents have more than 10 years of working experience.

\subsection{Data Analysis Technique}

In order to analyze the survey data, two statistical techniques were used. Firstly, the Statistical Package for Social Sciences (SPSS) version 19.0 was used. Next, the second statistical technique used was Partial Least Squares (PLS) approach to Structural Equation Modelling (SEM). PLS is usually recommended when the sample size is relatively small and non-normality (Chin \& Newsted, 1999). The analysis and interpretation of a PLS model is a two-staged process. First stage is the assessment of the reliability and validity to the measurement model and the second stage is the assessment of the structural model to test the hypotheses under study (Barclay et al., 1995).

\section{RESULTS}

\subsection{Assessment of the Measurement Model}

The first step in PLS analysis is to analyze the measurement model (or outer model) to determine how well the indicators (items in the constructs) load on the theoretically defined constructs. It was ensured in the beginning that the survey instrument is reliable and valid to measure the construct that were designed to measure. Thus, the reliability and validity analysis were performed to assess the measurement model. The purpose of the validity analysis is to test how well an instrument was developed to measure the particular concept it is intended to measure (Sekaran \& Bougie, 2010). Validity can be analyzed using construct validity, convergent validity, and discriminant validity. The purpose of reliability analysis is to test how consistent a measuring instrument can measure the concept of a study (Sekaran \& Bougie, 2010).

The individual item reliabilities use the loadings of the items to their respective constructs. According to Hair et al. (2010) standardized loadings should be greater than 0.50. In this study, since EO was used as one-dimensional construct, an analysis of principal components to assess the validity and reliability of the three dimensions in EO using SPSS 19.0 was carried out. The result showed that all items had a loading of higher than 0.50 as shown in Table 1 . Accordingly, the mean of the 14 items that measured the innovativeness, proactiveness and risk taking were taken as proxies of EO. However, it can be seen in Table 2 and Table 3 that there are a few items in CV and environmental dynamism constructs that were dropped due to low loadings. 
Table 1: Factor Pattern Matrix of Loadings and Cross-Loadings of the EO (using SPSS 19.0)

\begin{tabular}{cccc}
\hline \hline Construct & Innovativeness & Proactiveness & Risk Taking \\
\hline Innovativeness & & & \\
Innovation 1 & -0.012 & -0.051 & $\mathbf{0 . 7 3 2}$ \\
Innovation 2 & 0.061 & -0.009 & $\mathbf{0 . 5 2 4}$ \\
Innovation 3 & 0.140 & -0.001 & $\mathbf{0 . 8 1 0}$ \\
Innovation 4 & 0.058 & -0.047 & $\mathbf{0 . 8 6 4}$ \\
Innovation 5 & -0.246 & 0.104 & $\mathbf{0 . 7 6 8}$ \\
Proactiveness & & & \\
Proactiveness 1 & -0.087 & $\mathbf{0 . 8 6 6}$ & 0.036 \\
Proactiveness 2 & 0.009 & $\mathbf{0 . 8 5 2}$ & -0.004 \\
Proactiveness 3 & 0.018 & $\mathbf{0 . 8 8 3}$ & -0.120 \\
Proactiveness 4 & 0.078 & $\mathbf{0 . 8 2 6}$ & 0.086 \\
Risk Taking & & & \\
Risk 1 & $\mathbf{0 . 5 3 3}$ & 0.263 & 0.031 \\
Risk 2 & $\mathbf{0 . 7 9 3}$ & 0.038 & -0.049 \\
Risk 3 & $\mathbf{0 . 7 9 6}$ & 0.058 & 0.016 \\
Risk 4 & $\mathbf{0 . 8 5 2}$ & -0.049 & -0.047 \\
Risk 5 & $\mathbf{0 . 8 3 8}$ & -0.129 & 0.080 \\
\hline \hline
\end{tabular}

Table 2: Reliability and Validity for Firms’ Profitability Model

\begin{tabular}{cccc}
\hline \hline Construct & Loading & $\begin{array}{c}\text { Composite reliability } \\
(\mathbf{C R})=\mathbf{0 . 8 3 2}\end{array}$ & $\begin{array}{c}\text { Average variance extracted } \\
(\mathbf{A V E})=\mathbf{0 . 5 3 7}\end{array}$ \\
\hline EO & & 1.000 & 1.000 \\
CV & & 0.916 & 0.648 \\
CV_1 & 0.804 & & \\
CV_2 & 0.867 & & \\
CV_3 & 0.823 & & \\
CV_4 & 0.836 & & \\
CV_5 & 0.808 & & \\
CV_6 & 0.651 & & \\
Dynamism & & & \\
ED_1 & 0.664 & & \\
ED_2 & 0.841 & & \\
ED_3 & 0.640 & & \\
ED_4 & 0.819 & & \\
ED_5 & Dropped & & \\
\hline \hline
\end{tabular}

Table 3: Reliability and Validity for Firms’ Growth Model

\begin{tabular}{cccc}
\hline \hline Construct & Loading & $\begin{array}{c}\text { Composite reliability } \\
\text { (CR) }\end{array}$ & $\begin{array}{c}\text { Average variance extracted } \\
\text { (AVE) }\end{array}$ \\
\hline EO & & 1.000 & 1.000 \\
CV & & 0.895 & 0.635 \\
CV_1 & 0.9264 & & \\
\hline
\end{tabular}


Table 3: Reliability and Validity for Firms' Growth Model (con't)

\begin{tabular}{cccc}
\hline \hline Construct & Loading & $\begin{array}{c}\text { Composite reliability } \\
\text { (CR) }\end{array}$ & $\begin{array}{c}\text { Average variance extracted } \\
\text { (AVE) }\end{array}$ \\
\hline CV_2 & 0.7726 & & \\
CV_3 & 0.8247 & & \\
CV_4 & 0.8024 & & \\
CV_5 & 0.6281 & & \\
CV_6 & Dropped & 0.811 & \\
Dynamism & & & \\
ED_1 & Dropped & & \\
ED_2 & 0.852 & & \\
ED_3 & 0.737 & & \\
ED_4 & 0.735 & & \\
ED_5 & 0.534 & & \\
\hline \hline
\end{tabular}

In PLS, the composite reliability analysis was used to assess the reliability of the construct, interpreted like Cronbach's alpha for internal consistency reliability estimation, a composite reliability of 0.70 or greater is considered acceptable (Fornell \& Larcker, 1981). It can be seen in Table 2 and Table 3 that the composite reliability values ranged between 0.811 and 1.00 , which is more than the suggested cut off value of 0.70 . Thus, the survey instrument used in this study is reliable.

Table 4: Discriminant Validity: Cross Loadings (Firms’ Profitability Model)

\begin{tabular}{cccc}
\hline \hline & CV & Dynamism & EO \\
\hline CV_1 & $\mathbf{0 . 8 0 4}$ & -0.022 & 0.313 \\
CV_2 & $\mathbf{0 . 8 6 7}$ & -0.019 & 0.280 \\
CV_3 & $\mathbf{0 . 8 2 3}$ & -0.064 & 0.301 \\
CV_4 & $\mathbf{0 . 8 3 6}$ & -0.102 & 0.308 \\
CV_5 & $\mathbf{0 . 8 0 8}$ & -0.144 & 0.290 \\
CV_6 & $\mathbf{0 . 6 5 1}$ & -0.087 & 0.270 \\
Dynamism_1 & 0.062 & $\mathbf{0 . 6 6 4}$ & 0.085 \\
Dynamism_2 & 0.039 & $\mathbf{0 . 8 4 1}$ & 0.110 \\
Dynamism_3 & -0.002 & $\mathbf{0 . 6 4 0}$ & 0.147 \\
Dynamism_4 & -0.219 & $\mathbf{0 . 8 1 9}$ & -0.032 \\
EO & 0.353 & 0.082 & $\mathbf{1 . 0 0 0}$ \\
\hline \hline
\end{tabular}

Note: Bold values are loadings for items which are above the recommended value of 0.5 .

Table 5: Discriminant Validity: Cross Loadings (Firms’ Profitability Model)

\begin{tabular}{cccc}
\hline \hline & CV & Dynamism & EO \\
\hline CV_1 & $\mathbf{0 . 9 2 6}$ & 0.002 & 0.313 \\
CV_2 & $\mathbf{0 . 7 7 3}$ & 0.027 & 0.280 \\
CV_3 & $\mathbf{0 . 8 2 5}$ & -0.037 & 0.301 \\
CV_4 & $\mathbf{0 . 8 0 2}$ & -0.074 & 0.308 \\
CV_5 & $\mathbf{0 . 6 2 8}$ & -0.120 & 0.290 \\
Dynamism_2 & 0.077 & $\mathbf{0 . 8 5 2}$ & 0.110 \\
\hline
\end{tabular}


Table 5: Discriminant Validity: Cross Loadings (Firms' Profitability Model) (con't)

\begin{tabular}{cccc}
\hline \hline & CV & Dynamism & EO \\
\hline Dynamism_3 & 0.038 & $\mathbf{0 . 7 3 7}$ & 0.147 \\
Dynamism_4 & -0.157 & $\mathbf{0 . 7 3 5}$ & -0.032 \\
Dynamism_5 & 0.169 & $\mathbf{0 . 5 3 4}$ & 0.034 \\
EO & 0.335 & 0.099 & $\mathbf{1 . 0 0 0}$ \\
\hline \hline
\end{tabular}

Note: Bold values are loadings for items which are above the recommended value of 0.5.

After that, the discriminant validity was assessed using two measures ; i) cross loading, and; ii) Fornell Larcker's (1981) criterion. It indicates the degree to which one construct differs from the other. Firstly, Table 4 and Table 5 show that all of the items that were measuring a particular construct were loaded highly on that construct and were loaded lower on the other constructs. Therefore, the cross loading of the items in the measurement model's discriminant validity are satisfied. The second measure used for the discriminant validity assessment is the Fornell-Larcker criterion. It indicates the degree to which one construct differs from the others. The square root of the AVE is calculated to determine the construct discriminant validity. Thus, the square root of AVE should be greater than each of the construct correlations (Compeau et al., 1999). All the constructs of this study fulfilled these conditions because the diagonal elements are greater than the off-diagonal elements in the corresponding rows and columns as illustrated in Table 6 and Table 7. Thus, the result confirms that the Fornell-Larcker criterion is met.

Table 6: Discriminant Validity: Fornell-Larcker criterion (Firms’ Profitability Model)

\begin{tabular}{cccc}
\hline \hline & $\mathbf{1}$ & $\mathbf{2}$ & $\mathbf{3}$ \\
\hline 1. CV & $\mathbf{0 . 8 0 1}$ & & \\
2. Dynamism & -0.073 & $\mathbf{0 . 7 4 7}$ & \\
3. EO & 0.353 & 0.082 & $\mathbf{1 . 0 0 0}$ \\
\hline \hline
\end{tabular}

Note: Diagonals (in bold) represent the square root of AVE while the other entries represent the correlations.

Table 7: Discriminant Validity: Fornell-Larcker criterion (Firms’ Growth Model)

\begin{tabular}{cccc}
\hline & $\mathbf{1}$ & $\mathbf{2}$ & $\mathbf{3}$ \\
\hline 1. CV & $\mathbf{0 . 7 9 7}$ & & \\
2. Dynamism & 0.021 & $\mathbf{0 . 7 2 4}$ & \\
3. EO & 0.335 & 0.099 & $\mathbf{1 . 0 0 0}$ \\
\hline \hline
\end{tabular}

Note: Diagonals (in bold) represent the square root of AVE while the other entries represent the correlations.

Next, the assessment of convergent validity requires the examination of the average variance extracted (AVE) measurement (Fornell \& Lacker, 1981). The purpose of the $\mathrm{AVE}$ is to measure the amount of variance of the indicator which was accounted by the construct relative to the amount due to the measurement error. Thus, the AVE exceeded from 0.5 , which indicates that more than $50 \%$ of the indicators' variance can be captured 
by the construct (Boßow-Thies \& Albers, 2010: 596). From Table 2 and Table 3, it can be seen that the AVE values exceed the recommended value of 0.5 (Hair et al., 2010) which is in the range of 0.524 to 1.00 . The results illustrate adequate convergent validity and unidimensionality. Thus, all of the constructs are the valid measures of their respective constructs based on their parameter estimations (Chow \& Chan, 2008).

\subsection{Assessment of the Structural Model}

In the second stage, the structural models were assessed in order to test the relationships among hypothetical constructs. The bootstrapping was used to assess the structural model in PLS. The number of bootstrap samples used in this study is 1,000 and the number of cases are equal to the number of observations in the original sample which is 130 samples.

The dependent variables which are the firm's performance are divided into two dimensions; growth and profitability. This multidimensional firm's performance were assessed because CE may influence growth and profitability differently. Thus, making this study to comprise of two different models.

\subsection{The Main Effects Model}

Table 8 and 9 show the main effects model for both firm's profitability and growth. Table 8, which reports the result for firm's profitability, shows that only EO (Hypothesis 1a) is significant and positively related to firm's profitability $(\beta=0.279, \mathrm{p}$ $<0.01$ ). This model explains $0.8 \%$ of variance in firm's profitability. For firm's growth, Table 9 also shows that only one hypothesis is supported, which is the CV (Hypothesis $2 b)$. The CV is positive and significantly related to firm's growth and explains $0.6 \%$ of variance in firm's growth $(\beta=0.204, \mathrm{p}<0.01)$.

Table 8: Hypotheses and Results for Main Effect Model Firms’ Profitability Model)

\begin{tabular}{ccccc}
\hline \hline Hypothesis & Relationship & Path Coefficient & $\boldsymbol{t}$ Value & Supported \\
\hline H1a & EO $\rightarrow$ firms' profitability & 0.279 & $3.065^{* * *}$ & Yes \\
H1b & CV $\rightarrow$ firms' profitability & 0.010 & 0.124 & No \\
$R^{2}$ & & & 0.080 & \\
\hline \hline
\end{tabular}

Note: $* \mathrm{p}<.10 ; * * \mathrm{p}<.05 ; * * * \mathrm{p}<.01$.

Table 9: Hypotheses and Results for Direct Effects (Firms' Growth Model)

\begin{tabular}{|c|c|c|c|c|}
\hline Hypothesis & Relationship & Path Coefficient & $t$ Value & Supported \\
\hline H2a & EO $\rightarrow$ firms' growth & 0.002 & 0.038 & No \\
\hline $\mathrm{H} 2 \mathrm{~b}$ & $\mathrm{CV} \rightarrow$ firms' growth & 0.204 & $2.069 * * *$ & Yes \\
\hline$R^{2}$ & & & 0.060 & \\
\hline
\end{tabular}

Note: $* \mathrm{p}<.10 ; * * \mathrm{p}<.05 ; * * * \mathrm{p}<.01$. 
272 The Relationship between Corporate Entrepreneurship and Firm Performance: Evidence from Malaysian Large Companies

\subsection{The Moderating Effect of Environmental Dynamism}

Environmental dynamism was used as the moderating variable in this study. Out of the four hypotheses formulated, two hypotheses are supported. The environmental dynamism positively moderates the relationship between EO and firm's profitability ( $\beta$ $=0.204, p<0.05)$ and CV and firm's growth $(\beta=0.322, p<0.01)$. This supports Hypothesis 3a. These results are illustrated in Table 10 and Table 11. The variance explains $14.0 \%$ for firm's profitability model and 19.2\% variance explains firms' growth model.

Table 10: Hypotheses and Results for Interaction Effect Model (Firms’Profitability Model)

\begin{tabular}{ccccc}
\hline \hline Hypothesis & Relationship & $\begin{array}{c}\text { Path } \\
\text { Coefficient }\end{array}$ & $\boldsymbol{t}$ Value & Supported \\
\hline H3a & EO*Dynamism $\rightarrow$ firms' profitability & 0.158 & $1.896^{* *}$ & Yes \\
H3b & CV*Dynamism $\rightarrow$ firms' profitability & -0.122 & 1.515 & No \\
$R^{2}$ & & & 0.140 & \\
\hline \hline
\end{tabular}

Note: ${ }^{*} \mathrm{p}<.10 ; * * \mathrm{p}<.05 ; * * * \mathrm{p}<.01$.

Table 11: Hypotheses and Results for Moderating Effects (Firms' Growth Model)

\begin{tabular}{ccccc}
\hline Hypothesis & Relationship & Path Coefficient & $\boldsymbol{t}$ Value & Supported \\
\hline H4a & EO*Dynamism $\rightarrow$ firms' growth & 0.032 & 0.649 & No \\
H4b & CV $*$ Dynamism $\rightarrow$ firms' growth & 0.322 & $2.242^{* * *}$ & No \\
$R^{2}$ & & & 0.192 & \\
\hline \hline
\end{tabular}

Note: ${ }^{*} \mathrm{p}<.10 ; * * \mathrm{p}<.05 ; * * * \mathrm{p}<.01$.

\section{DISCUSSION}

This study investigates the relationship between CE dimensions and firm performance among large sized firms in Malaysia. Consistent with the previous researches' findings, this study also reveals that the CE practices in large firms have significant effects on the firm performance. Large companies in Malaysia are important for economic development as they are the largest contributor to the national earning export and GDP. Therefore, to study on their performance is a worthwhile scholarly endeavour.

The EO is found to increase the firm's profitability but has no significant relationship with firm's growth. The finding is consistent with prior studies that showed EO to be positively related to the firm's profitability (i.e, Hakala, 2013, Kemelgor, 2002, Moreno \& Casillas, 2008). In other words, the innovativeness, proactiveness and risk taking of the large firms contribute positively towards the firms' profitability and this relationship is also moderated by the environmental dynamism. It can also be said that with highly uncertain and unpredictable environments, the firms are more entrepreneurial and lead to higher firm’s profitability (Miller \& Friesen, 1983; Miller, 1988; Zahra, 1993). 
In contrast, the CV is only positively and significantly related to the firm's growth but has no significant relationship with the firm's profitability. The possible reason for this is because the profitability of the firm may be affected in short term due to the expenses in purchasing new venture, cost of merger, alliances and funding new venture (Zahra \& Garvis, 2000). This relationship is also moderated by the environmental dynamism. The $\mathrm{CV}$ is positively related to a firm's growth because the business expands and new addition in current products or services line increases the sales of the firm. This is similar to a previous research conducted among 58 large and medium sized Chinese enterprises which found that the venturing activities are positively related to overall perceptual firm performance but has no positive effect on ROI and net profit (Chen et al., 2005).

\section{CONCLUSION}

The findings imply that Malaysian large sized firms need to pay more attention on increasing their entrepreneurial effort to achieve growth and profitability. Among the entrepreneurial efforts is the willingness to innovate, take-risks and proactive relative to market place opportunities and to diversify their business operation.

In order to overcome the problems faced by the public listed companies such as suffering from lower levels of profitability, declining survival rates and failure to present quality, balanced and meaningful strategies, they must move towards implementing CE strategies in their operations. CE activities such as innovativeness, proactiveness, risk taking (EO dimensions), and CV were found to be positively related to firm profitability, and growth. Thus, in order to survive and prosper, large firms must use their resources and capabilities to create competitive advantage so that they can not only obtain higher performance but also outperform their rivals.

The willingness of the firms to engage in and support new ideas, novelty, experimentation, and creative processes that may result in new products, services, or technological processes will capture the customers' preferences that are rapidly changing. Consequently, the firms' profitability will increase due to the firm's ability to offer various lines of products and services. This also will cut costs by improving or using new systems and more sophisticated technology.

The firm must also be more proactive in bringing products or services to the markets in order to be ahead of other rivals. This is to seize available opportunities in the dynamic environments where fewer opportunities exist. The proactive firm does not only look for business opportunities but also aims to shape the environment in order to influence trends and create demands. This forward-looking perspective enables the proactive firm 
to anticipate future demands and become the first to introduce new product or services. Thus, being the first mover, has its own advantages because the firm can capture extraordinarily high profits and have a head start in establishing brand recognition.

In order to be more entrepreneurial and create competitive advantage, the firm must be able to take risks by committing substantial amounts of resources for high-risk projects with chances of very high returns. The large firms' willingness to take risks in introducing new technologies or processes is essential in order to capture business opportunities and create new demands. Even if the new creation may not be acclaimed by customers, large firms can take it as a learning process and improve on the products when necessary. It is empirically proven in this study that being a risk taker in business leads to higher firm growth and profitability. These strategy combinations are to enhance sustainable competitive advantage, also leading to higher performance. Therefore, EO is the source of competitive advantage that cannot be perfectly imitated, substituted, or traded, and is a valuable resource of the firm.

It is also recommended that the firm continuously encourage learning to create new knowledge about new products, services, process, technologies, markets and others. In the $21^{\text {st }}$ century business, knowledge is recognised as the most salient competitive advantage. CV activities such as entering new industries, acquisition, sponsoring new venture activities, and launching new business contributes significantly to the firm's growth. The firms obtain new knowledge through learning from their partners or new ventures about new technologies, system, practices, and appropriate management style. The new knowledge expedites and stimulates generation of new idea and the ability to visualize the future customers' preferences. These will possibly improve the firm's growth.

The shareholders and managers will also gain important information regarding the effects of environmental dynamism on the firm's strategies and firm performance. The findings in this study will enable the shareholders and managers to understand the role of the environment on performance of the firm because $\mathrm{CE}$ activities differ, depending on the type of environment a firm faces. The firms must increase their innovativeness, risk taking, and CV during uncertain business environments. This is to achieve higher firm performance in both profit and growth. Therefore, the firm must be ready to face the challenges in order to be successful. The better prepared the firm, the better they will be able to pre-empt the uncertain environments and better prepared to face impending the obstacles. In other words, the more preparation that the firms make, the more opportunities they will be able to identify and capitalize on, in dynamic and hostile environments. The managers should know that the firm must learn, adapt, improve and change to tackle the challenges faced and capitalise on the opportunities in order to survive in fiercely competitive business environments. 


\section{LIMITATIONS AND FUTURE RESEARCH SUGGESTIONS}

Although this study made significant contributions to the body of knowledge and to the determinants of the large sized firm performance, like other studies, this study also has some limitations and suggestions for some avenues for future research. First of all, the models that have been used in this research are somewhat simple. As a result, it is essential to consider additional variables such as those related to other business strategies and to the firm's performance dimensions. This will give better understanding regarding the relationship between the EO and the various dimensions of performance. Secondly, in this study, cross-sectional design was used rather than longitudinal design. Future research should consider exploring the causal relationships among the research variables using longitudinal design for a better premise. It is hoped that these results encourage future researchers to explore the unique role of each dimension in EO (innovativeness, proactiveness, and risk taking) and CV (internal CV and external CV). Repeating this given survey in the future will mitigate this problem.

\section{REFERENCES}

Andersén, J. (2010). A critical examination of the EO-performance relationship. International Journal of Entrepreneurial Behaviour \& Research, 16(4), 309328.

Antoncic, B. (2007). Intrapreneurship: A comparative structural equation modeling study. Industrial Management \& Data Systems, 107(3), 309-325.

Antoncic, B., \& Hisrich, R. D. (2001). Intrapreneurship: Construct refinement and crosscultural validation. Journal of Business Venturing, 16(5), 495-527.

Antoncic, B., \& Hisrich, R. D. (2003). Clarifying the intrapreneurship concept. Journal of Small Business and Enterprise Development, 10(1), 7-24.

Antoncic, B., \& Scarlat, C. (2008). Corporate entrepreneurship and organizational performance: a comparison between Slovenia and Romania. Paper presented at the 6th International Conference of the Faculty of Management Koper Congress Centre Bernardin, Slovenia, 24-26 November 2005, Slovenia.

Bank Negara Malaysia. (2005). Small and Medium Enterprise (SME) Annual Report 2005: Chapter 2: Status and Performance of Small and Medium Enterprises. Kuala Lumpur, Malaysia: Bank Negara Malaysia.

Barclay, D., Higgins, C., \& Thompson, R. (1995). The Partial Least Squares (PLS) approach to causal modeling: Personal computer adoption and use as an illustration (Special Issue on Research Methodology). Technology Studies, 2(2), 285-309.

Beaver, G. (2003). Small firms: owners and entrepreneurs. Strategic Change, 12(4), 177-183. 
276 The Relationship between Corporate Entrepreneurship and Firm Performance: Evidence from Malaysian Large Companies

Boßow-Thies, S., \& Albers, S. (2010). Chapter 25: Application of PLS in marketing: Content strategies on the Internet. In V. E. Vinzi, W. W. Chin, J. Henseler \& H. Wang (Eds.), Handbook of partial least squares: Concepts, methods and applications (pp.589-604) United Kingdom: Springer.

Burgelman, R. A. (1983). A Model of the Interaction of Strategic Behavior, Corporate Context, and the Concept of Strategy. Academy of Management Review, 8(1), 61-71.

Burns, P. (2005). Corporate entrepreneurship. United Kingdom, UK: Palgrave Macmillan.

Burns, T., \& Stalker, G. (1961). The management of innovation. Chicago: Quandrangle Books.

Chen, J., Zhu, Z., \& Anquan, W. (2005). A system model for corporate entrepreneurship. International Journal of Manpower, 26(6), 529 - 543.

Chin, W. W., \& Newsted, P. R. (1999). Structural Equation Modeling analysis with small samples using Partial Least Squares. In R. H. Hoyle (Eds.), Statistical strategies for small sample research (pp. 307-341). Thousand Oaks, California: Sage Publications.

Chow, W. S., \& Chan, L. S. (2008). Social network and shared goals in organizational knowledge sharing. Information Management, 45(7), 24-30.

Compeau, D. R., Higgins, C. A., \& Huff, S. (1999). Social cognitive theory and individual reactions to computing technology: A longitudinal-study. MIS $Q$, 23(2), 145-158.

Covin, J. G. \& Slevin D. P. (1986). The development and testing of an organizationallevel entrepreneurship scale. Wellesley, MA: Babson College.

Covin, J. G., \& Slevin, D. P. (1986). The development and testing of an organizationallevel entrepreneurship scale. Wellesley, Massachusetts: Center for Entrepreneurial Studies, Babson College.

Covin, J. G., \& Wales, W. J. (2011). The measurement of entrepreneurial orientation. Entrepreneurship Theory and Practice, 36(4), 677-702.

Covin, J. G., \&Lumpkin, G. T. (2011). Entrepreneurial orientation theory and research: reflections and needed construct. Entrepreneurship Theory and Practice, 35(5), 856-872.

Covin, J. G., Green, K. M., \& Slevin, D. P. (2006). Strategic process effects on the entrepreneurial orientation sales growth rate relationship. Entrepreneurship Theory \& Practice, 30(1), 57-81.

Covin, J., \& Miles, M. P. (1999). Corporate entrepreneurship and pursuit of competitive advantage. Entrepreneurship Theory and Practice, 23(3), 47-63.

Dalziel, T. (2005). The influence of boards and top management teams on corporate entrepreneurship. Doctoral Dissertation, University of Cincinnati.

de Vasconcellos e Sa, J. A. S., \& Hambrick, D. C. (1989). Key success factors: test of a general theory in the mature industrial sector. Strategic Management Journal, 10(4), 360-383. 
Department of Statistics. (2012). Economic Census 2011 Profile of Small and Medium Enterprise. Putrajaya, Malaysia: Department of Statistics.

Dess, G. G., \& Lumpkin, G. T. (2005). The role of entrepreneurial orientation in stimulating effective corporate entrepreneurship. Academy of Management Executive, 19(1), 147-156.

Donahoe, J., Schefter, P., \& Harding, D. (2001). Corporate venturing: management fad or lasting trend? Boston: Bain \& Company Inc.

Fama, E., \& French, K. (2004). New lists: fundamentals and survival rates. Journal of Financial Economics, 73(2004), 229-269.

Fornell, C., \& Lacker, D. F. (1981). Evaluating structural equation models with unobservable variables and measurement error. Journal of Marketing Research, 18(1), 39-50.

Guth, W., \& Ginsberg, A. (1990). Guest editors' introduction: Corporate entrepreneurship. Strategic Management Journal, 11, 5-15.

Hair, J. F., Black, W. C., Babin, B. J., \& Anderson, R. E. (2010). Multivariate data analysis. Upper Saddle River: Prentice-Hall.

Hakala, H. (2013). Entrepreneurial and learning orientation: effects on growth and profitability in the software sector. Baltic Journal of Management, 8(1), 102118.

Handfield, R., Petersen, K., Cousins, P., \& Lawson, B. (2009). An organizational entrepreneurship model of supply management integration and performance outcomes. International Journal of Operations \& Production Management, 29(2), 100-126.

Jantunen, A., Puumalainen, K., Saarenketo, S., \& Kyläheiko, K. (2005). Entrepreneurial orientation, dynamic capabilities and international performance. Journal of International Entrepreneurship, 3(3), 223-243.

Jiang, X. Yang, Y., Pei, Y. L., \& Wang, G. (2014). Entrepreneurial orientation, strategic alliances, and firm performance: Inside the Black Box, Long Range Planning. doi: 10.1016/j.lrp.2014.09.003.

Karacaoglu, K., Bayrakdaroğlu, A., \& San, F. B. (2013). The impact of corporate entrepreneurship on firms' financial performance: Evidence from Istanbul stock exchange firms. International Business Research, 6(1), 163-175.

Keh, H. T., Nguyen, T. T. M., \& Ng, H. P. (2007). The effects of entrepreneurial orientation and marketing information on the performance of SMEs. Journal of Business Venturing, 22(4), 592-611.

Kemelgor, B. H. (2002). A comparative analysis of corporate entrepreneurial orientation between selected firms in the Netherlands and the USA. Entrepreneurship \& Regional Development, 14(1), 67-87.

Knight, G. A. (1997), Cross-Cultural reliability and validity of a scale to measure firm entrepreneurial orientation. Journal of Business Venturing, 12(3), 213-225. 
278 The Relationship between Corporate Entrepreneurship and Firm Performance: Evidence from Malaysian Large Companies

Knight, R. M. (1989). Technological innovation in Canada: a comparison of independent entrepreneurs and corporate innovators. Journal of Business Venturing, 4(4), 281-288.

Kreiser, P., Marino, L., \& Weaver, M. (2002). Assessing the psychometric properties of the entrepreneurial orientation scale: a multi-country analysis. Entrepreneurship Theory and Practice, 26(4), 71-94.

Lawrence, P., \& Lorsch, J. (1967). Organizations and environment. Boston: Harvard University Press.

Liu, C. H., \& Lee, T. (2015). Promoting entrepreneurial orientation through the accumulation of social capital, and knowledge management. International Journal of Hospitality Management, 46(April), 138-150.

Lumpkin, G. T., \& Dess, G. G. (1996). Clarifying the entrepreneurial orientation construct and linking it to performance. The Academy of Management Review, 21(1), 135-172.

Lumpkin, G. T., \& Dess, G. G. (2001). Linking two dimensions of entrepreneurial orientation to firm performance: The moderating role of environment and life cycle. Journal of Business Venturing, 16(5), 429-451.

MacMillan, I. C., Block, Z., \& Narasimha, P. N. S. (1986). Corporate venturing: alternatives, obstacles encountered, and experience effects. Journal of Business Venturing, 1(2),177-91.

Miller, D. (1988). Relating Porter's business strategies to environment and structure: analysis and performance implications. Academy of Management Journal, 31(2), 280-308.

Miller, D., \& Breton-Miller, I. L. (2011). Governance, social identity, and entrepreneurial orientation in closely held public companies. Entrepreneurship Theory and Practice, 35(5), 1051-1076.

Miller, D., \& Friesen, P. H. (1982). Innovation in conservative and entrepreneurial firms: Two models of strategic momentum. Strategic Management Journal, 3(1), 1-26.

Miller, D., \& Friesen, P. H. (1983). Strategy-making and environment: The third link. Strategic Management Journal, 4(3), 221-235.

Moreno, A. M., \& Cassilas, J. C. (2008). Entrepreneurial orientation and growth of SMEs: a causal model. Entrepreneurship Theory and Practice, 32(3), 507-528.

Morris, M. H., Kuratko, D. F., \& Covin, J. G. (2008). Corporate entrepreneurship and innovation ( $2^{\text {nd }}$ Eds.). USA: South-Western Cengage Learning.

Narayanan, V. K., Yang, Y., \& Zahra, S. A. (2009). Corporate venturing and value creation: A review and proposed framework. Research Policy, 38(1), 58-76.

Oster, S. (1990). Modern strategic analysis. New York: Oxford University Press.

Pinchot, G. (1985). Intrapreneuring: Why You Don't have to Leave the Corporation to Become an Entrepreneur. New York: Harper and Row. 
Rauch, A., Wiklund, J., Lumpkin, G. T., \& Frese, M. (2009). Entrepreneurial orientation and business performance: An assessment of past research and suggestions for the future. Entrepreneurship Theory and Practice, 33(3), 761-787.

Reijonen, H., Hirvonen, S., Nagy, G., Laukkanen, T., \& Gabrielsson (2015). The impact of entrepreneurial orientation on B2B branding and business growth in emerging markets. Industrial Marketing Management, 51, 35-46.

Sekaran, U., \& Bougie, R. (2010). Research methods for business: A skill building approach. West Sussex, United Kingdom: John Wiley \& Son Ltd.

Sharma, P., \& Chrisman, J. (1999). Towards the reconciliation of the definitional issues in the field of corporate entrepreneurship. Entrepreneurship Theory and Practice,19(3),11-28.

Soininen, J., Martikainen, M., Puumalainen, K., \& Kylaheiko, K. (2011). Entrepreneurial orientation: growth and profitability of Finnish small- and medium-sized enterprises. International Journal of Production Economics, 140(2), 614-621.

Stevenson, H. H., Roberts, M. J., \& Grousbeck, H. I. (1985). New Business Ventures and the Entrepreneur. Homewood, Illinois: Richard D. Irwin Inc.

Tajeddini, K. (2010). Effect of customer orientation and entrepreneurial orientation on innovativeness: evidence from the hotel industry in Switzerland. Tourism Management, 31(2010), 221-231.

The Sun Daily. (2010, July 20). 99 delisted, 46 in financial difficulties. The Sun Daily. Retrieved from http://www.thesundaily.my/node/140511.

Vesper, K. H. (1990). New Venture Strategies (Rev. Eds.). Englewood Cliffs, New Jersey: Prentice-Hall.

von Hippel, E. (1977). Successful and failing internal corporate ventures: An empirical analysis. Industrial Marketing Management, 6(3), 163-174.

Wagner, E. R., \& Hansen, E. N. (2005). Innovation in large versus small companies: insights from the US wood products industry. Management Decision, 43(6), 837-850.

Wiklund, J. (1999). The sustainability of the entrepreneurial orientation-Performance relationship. Entrepreneurship Theory and Practice, 24(1), 37-48.

Wiklund, J., \& Shepherd, D. (2005). Entrepreneurial orientation and small business performance: A configurational approach. Journal of Business Venturing, 20(1), 71-91.

Yoo, S.-J. (2001). Entrepreneurial orientation, environment scanning intensity, and firm performance in technology-based SMEs. In W. D. Bygrave, C. G. Brush, P. Davidsson, G. P. Green, P. D. Reynolds, \& H. J. Sapienca (Eds.), Frontiers of Entrepreneurship Research (pp. 365-367). Wellesley, MA: Babson College.

Zahra, S. A. (1991). Predictors and financial outcomes of corporate entrepreneurship: an exploratory study. Journal of Business Venturing, 6(4), 259-285.

Zahra, S. A. (1993). A conceptual model of entrepreneurship as firm behaviour: a critique and extension. Entrepreneurship: Theory \& Practice, 17(4), 5-22. 
Zahra, S. A. (1996). Governance, ownership, and corporate entrepreneurship: the moderating impact of industry technological opportunities. Academy of Management Journal, 39(6), 1713-1735.

Zahra, S. A., \& Bogner, J. G. (2000). Technology strategy and software new ventures' performance: exploring the moderating effect of the competitive environment. Journal of Business Venturing, 15(2), 135-173.

Zahra, S. A., \& Covin, J. G. (1995). Contextual influences on the corporate entrepreneurship performance relationship: a longitudinal analysis. Journal of Business Venturing, 10(1), 43-58.

Zahra, S. A., \& Garvis, D. M. (2000). International corporate entrepreneurship and firm performance: the moderating effect of international environmental hostility. Journal of Business Venturing, 15(5-6), 469-492.

Zahra, S. A., \& George, G. (2002). Absorptive capacity: a review and reconceptualization. The Academy of Management Review, 27(2), 185-203.

Zhang, Y., \& Zhang, X. E. (2012), the effect of entrepreneurial orientation on business performance: A role of network capabilities in China. Journal of Chinese Entrepreneurship, 4(2), 132 - 142. 